\title{
COMMUNICATION PETTERNS OF COACHES AND STUDENTS IN CULTIVATING DISCIPLINE OF MEMORIZING THE QUR'AN
}

\author{
Qudratullah \\ IAIN Bone, Indonesia \\ qudratullah@iain-bone.ac.id \\ Nor Aswinda \\ IAIN Bone, Indonesia \\ aswindahnor2@gmail.com \\ Najamuddin \\ IAIN Bone, Indonesia \\ mhmdnaja41@gmail.com
}

\begin{abstract}
This research aims to determine the pettern of communication between Coaches and students in disciplining the memorization of the Qir'an at the Baitul Al-Muqarramah Foundation in Bone Regency. Qualitative research methods are used in this research by conducting interviews. Interviews wew conducted with informants who were Coaches at the Baitul Al-Muqarramah Foundation in Bone Regency. The results showed the Coaches in the Baitul Al-Muqarramah Foundation used verbal and nonverbal communication. There are two communication petterns that are used there are also two namely interpersonal communication petterns and group communication petterns. The petterns of group communication is more dominant used in this foundation, while interpernonal communication is usually applied to students who are less optimal in directing group communication. Where the pettern of group communication is more dominant applied in the process of direction every day. As with interpersonal communication, this communication pettern is usually applied to a particular situation. For axample, there is one student who cannot be fostered if trough the communication petterns of the group. Proven trought group communication implemented by the Coach, able to discipline student to memorize the Qur'an and make student achieve targets that have been determined with a dominant scale. Even trought this group communication, the time of a Coach can be more efficient than interpersonal communication which requires the trainer
\end{abstract}


to meet one-onone with his students. The obstacle factors of the Coaches are so unable to discipline the memorization of the Qur'an by their students namely; first, the psychological factors and habit factor od the students.

Keywords: Communication Pettern; Coach; Student; Memorization of The Qur'an.

\begin{abstract}
Abstrak
Penelitian ini bertujuan untuk mengetahui pola komunikasi pembina dengan santri dalam mendisiplinkan hafalan Al-Qur'an di Yayasan Baitul AlMuqarramah Kabupaten Bone. Metode penelitian kualitatif digunakan dalam penelitian ini dengan melakukan wawancara. Wawancara dilakukan kepada informan yang merupakan pembina dalam Yayasan Baitul Al-Muqarramah Kabupaten Bone. Hasil penelitian menunjukkan bahwa pembina dalam yayasan Baitul Al-Muqarramah menggunakan komunikasi verbal dan nonverbal. Terdapat dua pola komunikasi yang digunakan juga ada dua yaitu pola komunikasi interpersonal dan pola komunikasi kelompok. Pola komunikasi kelompok lebih dominan digunakan dalam yayasan ini, adapun komunikasi interpersonal biasa diterapkan pada santri yang dalam pengarahan komunikasi kelompok kurang maksimal. Di mana pola komunikasi kelompok lebih dominan diterapkan dalam proses pengarahan setiap harinya. Lain halnya dengan komunikasi interpersonal, pola komunikasi ini biasanya diterapkan pada suatu keadaan tertentu. Misalnya, ada salah satu santri yang tidak bisa dibina apabila melalui pola komunikasi kelompok tadi. Terbukti melalui komunikasi kelompok yang diterapkan oleh pembina, mampu mendisiplinkan santri untuk menghafalkan Al-Qur'an serta membuat santri untuk mencapai target yang telah ditentukan dengan skala dominan. Melalui komunikasi kelompok inipun, waktu dari seorang pembina bisa lebih efisien dibandingkan dengan komunikasi interpersonal yang mengharuskan pembinanya bertatap muka satu per satu dengan santrimya. Adapun faktor hambatan dari para pembina sehingga tidak mampu untuk mendsiplinkan hafalan Al-Qur'an para santrinya yaitu; faktor psikologis dan faktor kebiasaan santri.
\end{abstract}

Kata Kunci: Pola Komunikasi; Pembina; Santri; Hafalan Al-Qur'an.

Accepted: May 11, 2020 Reviewed: May 14, 2020 Published: June 1, 2020

\title{
Introduction
}

Communication is knowledge and skills that are very important and useful for everyone. By communicating, a person can communicate intrapersonal or with oneself, get to know yourself, convince yourself to 
prepare messages to be conveyed to others, make decisions after consideration and evaluate or evaluate yourself. In addition to intrapersonal communication, one can also communicate interpersonal, that is interacting with others, valuing others, and expressing yourself to others. One can also communicate with groups and organizations. With this communication a person can solve problems develop new ideas, get new ideas from other people, and share information and knowledge with others. Through this communication, a person has a working relationship both at work and in the social environment that can be lived in groups and organizations (Chen, 2013).

In general, communication is divided into two, namely verbal communication and nonverbal communication. Verbal communication is communication in its delivery using words, whether it is oral or written. Conversely, nonverbal communication is communication where the message is conveyed without words such as symbols or codes. Verbal communication is the communication most widely used in interacting between people. Through words, a person can express feelings, emotions, ideas, thoughts, convey facts, and others. In addition, without us realizing that nonverbal communication is in fact far more widely used than verbal communication. In communicating, nonverbal communication is almost automatically used. Therefore, nonverbal communication is permanent and exists (Hardjana, 2003). Nonverbal communication is more spontaneous expressing something, for example adults, who although hungry can make small talk to refuse the food that is offered. Unlike babies, they will spontaneously cry when hungry (Hardjana, 2003).

In addition to the above form of communication, there is also the term communication pattern or also commonly referred to as a model, which is a system consisting of various components related to one another for the purpose of education in the community. Communication pattern is a process that is designed to represent the reality of the linkages of the elements covered along with sustainability, in order to facilitate systematic and logical thinking. Communication patterns consist of several types, namely: (a) Primary Communication Patterns, (b) Secondary Communication Patterns, (c) Linear Communication Patterns and Circual Communication Patterns (Astari, 2015). 
Communication is important for group activities, one of the characteristics of almost all groups is that some people talk too much and others too little, the surrounding situation does not seem to affect this pattern much. The most interesting aspect of this phenomenon is that it takes place regardless of the size of the group, regardless of the number of members, communication will follow a very regular pattern that can be presented with a logarithmic function (Sears et al., 2001).

Communication patterns can flow vertically and laterally. The vertical dimension is divided into two directions, namely down and up. Lateral communication patterns occur when communication occurs between members in the same work group, between members of the work group at the same level, between managers at the same level, or between personnel who are horizontally the same (Sears et al., 2001).

There are several communication models that are used in educational institutions, such as in public schools and boarding schools. For example some effective communication models in the learning process that are linked to learning theory; First the mechanistic model, this model consists of one way communication and two way communication, example of one way communication is the lecture method in the learning process where a teacher conveys a material then observed by the students. This one-way communication model requires educators to master the material so that their students can understand it well, but arguably this kind of communication is less effective because there is no feedback from students, in contrast to the two way communication model, in This model allows interaction between educators and students because of the feedback from students. Second, the psychological model, in this communication model explains that in the communication process, not only physical factors are involved, psychological aspects are also important in the communication process. An educator does not only play a role in giving understanding to his students about the material presented, educators must also be able to know and understand the psychological state of their students. Because psychological aspects of a person will be very influential in all aspects of life, one of them is the aspect of education that refers to learning activities (Naway, 2017).

Educational institutions such as Islamic boarding schools are more dominant in religious teachings, one of which is the memorization of the 
Qur'an. In a large Indonesian dictionary Islamic boarding school can be interpreted as a hostel, a place for students, or a place where students learn to recite the Qur'an. An Islamic boarding school is an Islamic educational institution led by a kiai where his students live in a pondok. The students in the hut, usually, learn, understand, and explore, and practice the teachings of Islam by giving priority to the importance of religious morals as a reference / guide to behavior in their daily lives (Kompri, 2018). The history of the Islamic boarding school, begun by a kiai who was visited by students who wanted to study religion, more and more students came to him, until there arose an initiative by the kiai to build a cottage / romance next to his house. Starting from a cottage that was founded by the kiai and then increasing. The existence of the boarding school is increasingly popular, so that it is famous everywhere, for example like the cottage that existed at the time of Wali Songo (Kompri, 2018).

The existence of Islamic boarding schools in Indonesia has a very large role, both for the progress of the teachings of Islam itself, as well as the progress of the Indonesian people as a whole. Based on the record, religious education activities in the archipelago had begun since 1596, which activity was later known as the boarding school. Initially, the orientation and model of organizing Islamic boarding school education were directed to create religious scholars (kiai) who had a mission to spread the teachings of Islam to the wider community. Until now, there have been many pesantren that hold school education in addition to madrasa education. There are several pesantren that open madrasas (tsanawiyah and aliyah) and also open public schools (junior and senior high schools) or even establish religious or public tertiary institutions (Kompri, 2018).

The communication model in pesantren can be seen from how a kiai, cleric and santri interact. Almost all communication processes that occur in pesantren are religious messages. Conversely, in terms of religion, religious preservation is essentially achieved through a communication process. The communication process in pesantren occurs through various activities including; classical learning processes and tutorials, rhetorical exercises, organizational activities, weekly dialogues and so on. All these 
activities construct various kinds of communication models that are adapted to social strata, psychological, and situation (Hartono, 2016).

The pesantren is now one of the most popular educational institutions because the methods of defense differ greatly from those in general. Religious science is also one of the advantages of Islamic boarding schools and does not rule out other general sciences. Pesantren is one of the educational institutions which not only emphasizes the religious sciences but also other general sciences such as mastering foreign languages.

In this era of increasingly rapid development of communication technology, resulting in changes that occur in society. For example, there are many teenagers who are more interested in reading what is on their mobile phones than reading the Qur'an especially when teenagers enter public schools. This is due to the assumption of adolescents that memorizing the Qur'an is difficult, and there is no habituation from parents regarding the Al Qur'an in early. This also causes parents to put their children in boarding schools, because these parents have not been able to guide their children. People in the days are preoccupied with the Koran either by reading it or memorizing it, they are good human beings, there are many hadiths that explain the importance of reading and memorizing the Qur'an, one of which is:

The Qur'an Will Become Ayafa'at on Judgment Day. The Prophet, Nabi Muhammad SAW said: Read the Qur'an, because it will come on the Day of Judgment as blessing for the shahibul Qur'an - HR Muslim (Moh. Fathurrozi, 2019).

The Coaches have a big role in guiding their students, especially as a substitute parent for students. That is, the Coach must make communication that can build a passion for learning in the environment. Good communication is needed so that the students feel at home in the hut and are able to achieve the targets without feeling constrained. because in the case example, there are some children who come out because they feel bored and feel unable to continue. The importance of communication between the Coach and students must always be done well and also need to minimize communication disruptions. The Coach has the aim of increasing the intelligence of the students and the students 
also have the goal of increasing their own intelligence with the knowledge of the Coach.

Baitul Al-Muqarramah Foundation is one of the pesantren in Bone Regency, precisely on the Welalangnge road. This foundation has a junior and senior high school level. There are many religious routines carried out, one of which is to recite at the morning and evening. The division of memorizing the Qur'an at the Foundation has only been around since last year. The Coach and teach the Al-Qu'an memorization method are certainly supported by appropriate communication patterns carried out by students who have different mindset and behavior. The increasing memorization of Al-Qur'an santri makes writers interested in exploring how the communication patterns applied by the Coach.

The author is interested in examining the pesantren educational institution, the Baitul Al-Muqarramah Foundation, because he sees from the coach who is so friendly and relaxed when invited to interact. Therefore, the authors are interested in knowing what communication patterns are applied in disciplining their students in religious study specifically in memorizing the Koran. Based on the description above, it can be drawn the formulation of the problem, namely how the pattern of communication between the coaches and students in the cultivation of the discipline of memorizing the Qur'an (Case Study of the Baitul A1Muqarramah Foundation Bone Regency).

\section{Research Method}

This study uses a qualitative method. According to Denzin and Lincoln (1994) qualitative research is research that uses a natural setting with the intention of interpreting phenomena that occur and is carried out by involving a variety of existing methods. Erickson (1968) states that qualitative research seeks to discover and illustrate narratively the activities carried out and the impacts from the actions taken on their lives. Based on the two meanings above, it can be concluded that qualitative research is data collected on a scientific setting with the intention of interpreting phenomena that occur where research is a key instrument (Anggito \& Setiawan, 2018).

The research method used in this research is interview and descriptive describing the characteristics of certain individuals, situations 
or groups. The interview method is one of the methods used in almost all qualitative research. Interview is a process of interaction carried out by two or more people, where both parties involved (interviewer and resource person) both parties have the same opportunity / right to ask and answer (Herdiansyah, 2015). Haris Herdiansyah expressed his opinion regarding the definition of interview in the context of qualitative research as follows:

"Interview is a process of communication interaction conducted by at least two people, based on availability and in a natural setting, where the direction of the conversation refers to the objectives set by prioritizing trust as the main foundation in the process of understanding" (Herdiansyah, 2015).

This research refers to purposive sampling. According to Margono, the selection of a group of subjects in purposive sampling is based on certain characteristics that are considered to have a tight bearing on the characteristics of the population that have been known beforehand (Margono, 2005). In other words, the sample units contacted were adjusted to certain criteria applied based on the research objectives (Mamik, 2015). For example in this study regarding the communication pattern of the Trustees in disciplining the memorization of Al-Qur'an students in the Pondok Yayasan Baitul Al-Muqarramah Bone Regency. Then the sample to be interviewed is the cleric and cleric who become coaches in the classes of memorization of the Qur'an at that place. This study was conducted to determine the communication pattern of the Trustees in disciplining the memorization of the Qur'an on students in the Pondok Yayasan Baitul Al-Muqarramah.

\section{Results and Discussion}

Communication is very important in establishing interaction in order to achieve the goals that have been set together between the communicator and the communican. In everyday life communication is done by starting with the source of the message or referred to by the term communicator, both individuals and groups. Group communication is one of the forms of communication that is closely related to the daily life of humans as social beings. In addition, interpersonal communication is also a type of communication that is often done in establishing deeper, 
harmonious and close intimacy between one individual with another individual.

Communication is basically an activity of exchanging symbols. The symbol that is often used in communication is verbal language that is presented in the form of words, sentences, numbers and other descriptive narratives. Verbal language is a lot that implies a variety of instructions, statements, attitudes, self-condition, feelings and so forth issued through verbal. There are also nonverbal languages, languages that are full of cues without using spoken. One of them is body language.

The builder of the Baitul Al-Muqarramah foundation has a great responsibility in supporting a goal that has been set together. Guidance boarding schools must be able to strive for various ways to be able to advance the quality of their students. Moreover, that the coach in the cottage is a substitute for the role of parents for their students. Aside from being a substitute for the role of parents, the Trustees of the foundation must also be able to give direction and motivation to the students, especially when their students start to get bored in the foundation. The students need to be motivated and innovated in the guidance process so that they are even more active in achieving the targets set. A clear direction can also make the activity run more optimally. Likewise the Qur'anic memorization division in the Baitul Al-Muqarramah Foundation, there are three classes which are distinguished based on the level of ability of each of the students. There are 5 coaches consisting of 3 religious teachers, and 2 religious teachers. This coach always gives direction to the students for their memorization. Everyday, the students must face to report the results of their memorization of the Qur'an, in accordance with predetermined targets.

The coach at the Baitul Muqarramah Foundation, of course, interacts through verbal communication and nonverbal communication. Verbal communication is communication that is delivered in oral and written form. This form of communication requires tools in the form of language that is packaged in the form of speech or written words. In Language. The word can be a symbol that represents something, whether it is in the form of people, things, circumstances, events, and others. The meaning of the word itself comes from people's minds, there is no relationship between words and things. The ustadzah and ustadzah in the Baitul Al- 
Muqarramah foundation used this verbal communication to direct their students, of course by using language that was easy for them to understand and contained no emphasis. In addition to verbal communication, this foundation also uses nonverbal communication when interacting. Nonverbal communication itself can be in the form of body language, signs, actions or objects. Body language can be in the form of facial expressions, head movements, and hand gestures. Signs in nonverbal communication can be in the form of flags, signs, signs in sports. Then actions in nonverbal communication can deliver meaning. For example, someone who kicked the table while talking, closed the door loudly, and pressed the gas on the motor strongly. All of these actions have their own meaning. As for some functions of nonverbal communication, namely: As a complement to verbal communication, for example a family who comes home, we invite in and then shake his hand. It is important to have nonverbal communication in providing explanations and support with verbal communication. This nonverbal communication provides less chance of communication disruptions and misunderstanding in communication due to the assistance of such gestures or body language. Against verbal communication, this is like a friend of ours who is asked if he is sad, then he answers that it's okay even though his face looks gloomy and he also shed tears. The attitude and state of a person will be easily understood by paying attention to the gestures and facial mimics that exist in him. It can be said that nonverbal language is a language that naturally arises from a form of heart content that is difficult to hide. Reflexity and spontaneity of body movements are not processed and designed according to our own desires as the verbal language that we can compose properly.

The example of nonverbal communication used by a coach in the Baitul Al-Muqarramah foundation are: Directing his index finger towards the santri then swinging it downwards. This body language has a meaning, that students must be silent and pay attention back to the direction of the builder. Heads are nodded down while closing their eyes, which means that the students must be calm and attentive. The finger pointing to the Qur'an which implies the students to pay attention to their Qur'an. 
By knowing the nature of verbal and nonverbal language, we can use both kinds of language in our interactions with people efficiently and effectively (Hardjana, 2003). Each class held by a cleric or cleric numbered approximately 14-18 people in the age range of 13-17 years. Futhermore, each class certainly contains students who have different characteristics. There are among the students who can quickly memorize, those who are not so fast in memorizing the Qur'an.

The communication patterns used at this Foundation, namely interpersonal communication and group communication. Interpersonal communication is communication that is contained face to face and influence each other, listen, express statements, openness, sensitivity which is the most effective way of changing a person's attitudes, opinions and behavior with the effect of direct feedback. One indication that humans as social beings is the behavior of communication between humans. Human interaction with humans shows that everyone needs help from others around him. For that he communicates.

One type of communication that is high enough frequency is interpersonal communication or interpersonal communication. Interpersonal communication is the process of delivering and receiving messages between the sender of the message (sender) with the receiver either directly or indirectly. Communication is said to be direct (primary) if the parties involved in communication can share information without going through the media. While indirect communication (secondary) is characterized by the use of certain media.

Group communication is communication that takes place between several people in a "small" group such as in meetings, meetings, conferences and so on (Arifin, 1982). Michael Burgoon (in Wiryanto, 2009) defines group communication as face-to-face interaction between three or more people, with known goals, such as sharing information, protecting themselves, solving problems, where members can remember the personal characteristics of other members appropriately. The two definitions of group communication above have in common, namely the presence of face-to-face communication, and have a specific work plan arrangement to achieve group goals.

Group communication emphasizes communication that is group or more than two people. This communication has a common goal in a 
communication process. The amount of communicant will have consequences in the process of group communication. By him group communication is also classified in small group communication and large group communication. To classify it is not calculated from the amount mathematically but the communicant's opportunity to convey his response to the communicator (Effendy, 2008). In a group communication requires a group leader in moving the group members to complete group tasks in order to achieve common goals. The leader of the group must have certain qualities such as being accountable, competent, having more abilities, being honest, confident, etc (Muhammad, 2005).

A group is a group of people who have a common goal and interact with each other to achieve a common goal, get to know each other, and view them as part of the group (Mulyana, 2010). This group, for example: is a family, a discussion group, a problem-solving group, or a committee that is meeting to make a decision. In group communication, it also involves interpersonal communication. Therefore, most interpersonal communication theories apply to group communication as well.

The application of interpersonal communication patterns at the Baitul Muqaddimah foundation is carried out by a cleric / cleric to his students if there are several obstacles. For example, when there is a santri whose direction is less than the maximum when a supervisor gives group direction. Based on the interview, it can be seen that there are several santri children who need to be given personal direction. This communication can be considered more effective because both parties interact with each other by giving feedback, the party invited to talk will find it easier to express opinions without feeling embarrassed about being seen by others. In this case of communication, a coach must certainly provide a special time to talk to his students.

Therefore to face the obstacles of group communication, it is necessary to conduct interpersonal communication to solve problems that may be experienced by a santri. Therefore, a coach must have the ability to understand the psychological state of his students and be able to provide solutions that can solve problems the. This needs to be done so that good interactions are established. as is known that interpersonal communication is communication between two individuals who establish 
communication and interaction and provide feedback between one another (Wiryanto, 2010).

Basically, more dominant group communication patterns are used at the Baitul Al-Muqarramah Foundation. Every routine interaction carried out by the coaches and students is through group communication, including in the Tahfidz definition. Previously, all students who entered the Tahfidz definition must have gone through a selection process. After being declared qualified, all the students were then presented about what activities should be carried out. Then further direction by the coach is done through group communication with medium scale. Communication patterns like this can be said to be quite effective in disciplining students because only one or two students who really cannot be briefed if the communication scale of the group.

\section{Conclusion}

There are two forms of communication used at the Baitul AlMuqarramah Foundation, namely forms of verbal and nonverbal communication. Verbal communication is more dominant because it is given that in a cottage that is usually carried out the process of coaching continuously. In addition to verbal communication, verbal communication is usually used by the coaches to direct their students. For example: when the Qur'an is being read, and there is one student who is not focused, then the coach usually gives a signal to the students to refocus.

There are also two communication patterns used, interpersonal communication patterns and group communication patterns. Where, the pattern of group communication is more dominantly applied in the daily briefing process. As with interpersonal communication, this communication pattern is usually applied to a particular situation. For example, there is one student who cannot be fostered if through the communication patterns of the group. Evidently, through group communication implemented by the coach, is able to discipline students to memorize the Qur'an and make students to achieve targets that have been determined with a dominant scale. Through this group communication, the time of a coach can be more efficient compared to 
interpersonal communication that requires the trainer to meet face to face with his students. Of course, this will take more time.

There are several obstacles from the coaches so that they are unable to discipline the students' memorization of the Qur'an namely; First, the psychological factors of the santri. This can be explained through the personality of the students who indeed sometimes require special attention through interpersonal communication. Second, some habitual factors need adjustments for new things delegated to him, for example the target that must be achieved by students that day. Children's intellectual abilities vary, and therefore through personal understanding is expected to improve the things that become obstacles earlier. So in conclusion, the application of interpersonal communication patterns and group communication patterns are each effective on their respective scales. Both of these communication patterns have their advantages and disadvantages, depending on the conditions.

\section{Bibliography}

Anggito, A., \& Setiawan, J. (2018). Metodologi penelitian kualitatif. Sukabumi: Jejak Publisher.

Arifin, A. (1982). Strategi komunikasi sebuah pengantar ringkas. Bandung: Armico.

Astari, D. R. (2015). Pola Komunikasi Sales Promotion Girl (Spg) Dalam Pemasaran Produk Rokok Di Lampung (Studi SPG rokok Djarum DSO B. Lampung dan SPG rokok Djarum DSO Kota Bumi) [Skripsi, Fakultas Ilmu Sosial dan Ilmu Politik]. http://digilib.unila.ac.id/7738/10/MOTO.pdf

Chen, F. (2013). Competence for Success 1-Keterampilan \& Pengetahuan. Jakarta: Gramedia Pustaka Utama.

Effendy, O. U. (2008). Dinamika komunikasi. Bandung: Remaja Rosdakarya. Hardjana, A. M. (2003). Komunikasi Interpersonal Dan Intrapersonal. Yogyakarta: Kanisius. 
Hartono, R. (2016). Pola Komunikasi di Pesantren: Studi tentang Model Komunikasi antara Kiai, Ustadz, dan Santri di Pondok Pesantren TMI Al-Amien Prenduan. al-Balagh: Jurnal Dakwah dan Komunikasi, 1(1), 67-100. https://doi.org/10.22515/balagh.v1i1.60

Herdiansyah;, H. (2015). Wawancara, Observasi, Dan Focus Groups: Sebagai Instrumen Penggalian Data Kualitatif. Jakarta: Rajawali Pers.

http://library.fip.uny.ac.id/opac/index.php?p=show_detail\&id=8151

Kompri. (2018). Manajemen \& Kepemimpinan Pondok Pesantren. Jakarta: Prenada Media.

Mamik, D. (2015). Metodologi Kualitatif. Sidoarjo: Zifatama Jawara.

Margono, S. (2005). Metodologi Penelitian Pendidikan. Jakarta: Rineka Cipta. https://opac.perpusnas.go.id/DetailOpac.aspx?id=635125

Moh. Fathurrozi. (2019, Agustus). Penjelasan tentang Syafaat Al-Qur'an. NU Online. https://islam.nu.or.id/post/read/110117/penjelasantentang-syafaat-al-qur-an

Muhammad, A. (2005). Komunikasi Organisasi. Bumi Aksara. //library.fis.uny.ac.id\%2Fopac\%2Findex.php\%3Fp\%3Dshow_detail\% 26id\%3D2284

Mulyana, D. (2010). Ilmu Komunikasi: Suatu Pengantar. Bandung: Remaja Rosdakarya.

Naway, F. A. (2017). Komunikasi \& Organisasi Pendidikan. Ideas Publishing. https://docplayer.info/116586470-Komunikasi-organisasipendidikan-dr-fory-armin-naway-m-pd.html

Sears, D. O., Fredman, J. L., \& Peplau, L. A. (2001). Psikologi sosial jilid $2 /$ (2nd ed.). Jakarta: Erlangga. http://library.um.ac.id/freecontents/index.php/buku/detail/psikologi-sosial-jilid-2-david-o-sears- 
jonathan-l-fredman-l-anne-peplau-alih-bahasa-michael-adryanto10597.html

Wiryanto. (2009). Pengantar Ilmu Komunikasi. Jakarta: Grasindo.

Wiryanto. (2010). Teori Komunikasi Massa. Jakarta: Grasindo. https://openlibrary.telkomuniversity.ac.id/pustaka/9696/teorikomunikasi-massa.html 